\title{
Phosphorus uptake by fodder maize (Zea mays L.) under different cadmium levels with or without farm yard manure in loamy sand and clayey soils of Gujarat
}

\section{SANDIPKUMAR V. RATHOD, N.N. CHAUDHARY AND J.K. PARMAR}

\section{MEMBERS OF RESEARCH FORUM: \\ Corresponding author : SANDIPKUMAR V. RATHOD, \\ Department of Soil Science and Agricultural Chemistry, B.A. College of Agriculture, Anand Agricultural University, ANAND (GUJARAT) INDIA \\ Email: rathod6061@gmail.com}

Co-authors :

N.N. CHAUDHARY AND J.K. PARMAR, Department of Soil Science and Agricultural Chemistry, B.A. College of Agriculture, Agricultural University, ANAND (GUJARAT) INDIA

Received : $19.10 .2014 ;$ Revised : 01.11 .2014 ; Accepted : 18.11 .2014

\section{Summary}

A pot experiment was conducted during summer, 2013 by growing fodder maize (Zea mays L.) in loamy sand and clayey soils of Anand and Karvan with five levels of Cd (0.0, 2.5, 5.0, 7.5 and $10.0 \mathrm{ppm})$ and two levels of FYM (0 and $\left.10 \mathrm{t} \mathrm{ha}^{-1}\right)$ to assess the effect of Cd levels in present of FYM on phosphorus uptake by plant components and total phosphorus uptake by the crop. The result revealed that phosphorus uptake in plant components significantly decreased when $10.0 \mathrm{ppm} \mathrm{Cd}$ was added. The total $\mathrm{P}$ uptake by maize plant significantly decreased at each level of $\mathrm{Cd}$ application. The clayey soil recorded significantly more $\mathrm{P}$ uptake as compared to loamy sand soils. The phosphorus removal was significantly higher in FYM treated pot as compared to no FYM application.

Key words : Cadmium, Phosphorus uptake, Farm yard manure, Loamy sand, Clayey soils

How to cite this article : Rathod, Sandipkumar V., Chaudhary, N.N. and Parmar, J.K. (2014). Phosphorus uptake by fodder maize (Zea mays L.) under different cadmium levels with or without farm yard manure in loamy sand and clayey soils of Gujarat. Asian J. Soil Sci., 9(2): 280-283. 